\title{
Astringency, a textural defect in dairy products
}

\author{
L Lemieux, RE Simard \\ Centre de recherche STELA, Département de sciences et technologie des aliments, \\ Pavillon Paul-Comtois, Université Laval, Sainte-Foy (Québec), Canada G1K 7P4
}

(Received 24 September 1993; accepted 9 February 1994)

\begin{abstract}
Summary - Like bitterness, astringency is a defect liable to affect dairy products, but it has not been studied as extensively. This review article attempts first to clarify the confusing use in the literature of the term 'astringent' to describe some associated textural defects of dairy products and to better define astringency. Although astringency in dairy products might originate from two known causes: compounds resulting from heat treatment and proteolytically induced peptides (probably Cterminal breakdown products of $\beta$-casein), the presence of phenolic compounds could also be a plausible cause. Astringent compounds reported to be present in many dairy products are listed, as well as some methods of extraction and isolation.
\end{abstract}

\section{astringency / dairy products / peptide}

Résumé - L'astringence, un défaut de texture dans les produits laitiers. Parmi les défauts susceptibles d'être rencontrés dans les produits laitiers, l'amertume est celui qui a été le plus étudié. Toutefois, l'astringence mérite également que l'on y prête attention. Aussi, cet article tente, en premier lieu, d'éclairer la confusion qui existe sur l'utilisation du mot astringent dans la description de certains défauts de texture rencontrés dans les produits laitiers. Bien que l'astringence des produits laitiers soit attribuable principalement à des composés résuitant de l'effet des traitements thermiques et de la protéolyse, notamment peptides dérivés de la caséine $\beta$, des composés phénoliques pourraient également être impliqués dans ce défaut. Cette revue de synthèse traite des différents produits lactés dans lesquels l'astringence est rencontrée, ainsi que des méthodes d'extraction et d'isolation de ces composés astringents.

astringence / produit laitier / peptide 


\section{INTRODUCTION}

In a previous report (Lemieux and Simard, 1991) on defects in dairy products, the factors likely to influence the development of bitterness, mainly in cheeses, were reviewed. Bitter peptides originating from caseins - their formation, isolation and identification, structure, masking and inhibition - were reviewed in an exhaustive second report (Lemieux and Simard, 1992). Although the exact role of different proteolytic enzyme systems in the development of bitterness is not fully understood, $\alpha_{s 1}$ casein has been recognized as always inducing more bitterness than $\beta$-casein. So, when extracting peptides, more bitter peptides originated from $\beta$-casein than from $\alpha_{\mathrm{s} 1^{-}}$ casein are detected. However, the resistance of $\beta$-casein toward the enzymes involved in the cheese ripening process is higher than that of $\alpha_{s 1}$-casein. So, when extracting peptides, more bitter peptides originated from $\beta$-casein than from $\alpha_{\mathrm{s} 1}$ casein are detected. This particularity could explain the tendency to associate $\beta$-casein with bitterness.

As stated previously (Lemieux and Simard, 1992), there are five primary tastes: sweet, sour, salty, bitter and umami (which means 'agreable'). Not only the primary but also the secondary tastes, such as astringency, metallicity, and hotness, contribute to the characteristic taste of foods. Mouthfeel properties that are commonly defined in

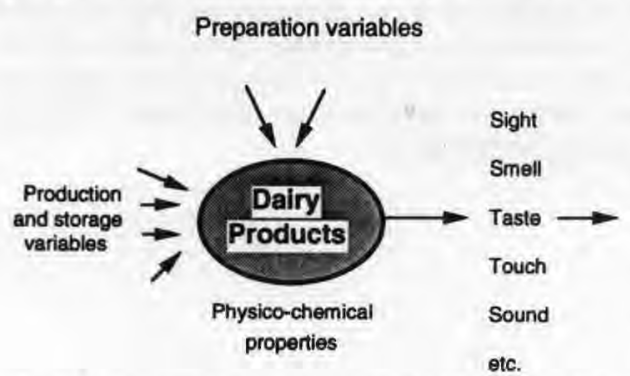

terms of body texture or consistency are detected by the sense of touch or feel rather than taste. Combined with flavour, they are essential components of organoleptic quality and so influence consumer acceptability. Viscosity, texture and astringency are the principal criteria related to tactile properties. However, there is confusion in the literature around the term 'astringency'. Whereas bitterness is perceived primarily on the back of the tongue, astringency is detectable throughout the oral cavity (Rouseff, 1990). Although astringency has not been studied as extensively as bitterness, it is typically encountered in reconstituted powdered milk and sterilized milk products.

Detectability, intensity, quality and reactions are the four classes of sensory techniques applied to foods and beverages. The last two of these are respectively presented in figure 1 by several specific sensory attributes and preferences (Land, 1983). Moreover, the quality of food consists of safety, nutritional value and acceptability, all of which are interrelated.

The need to develop a rational system and nomenclature for describing and translating textural qualities into precisely defined measurable properties was noted many years ago by Szczesniak (1963). She has pointed out several inherent problems with the nomenclature used to describe textural characteristics in terms of simple words. Thus, a number of terms may be used to

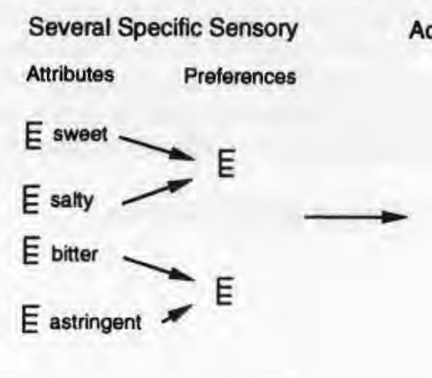

Fig 1. Dairy products. Influence of different variables on their sensory quality.

Produits laitiers. Influence de différentes variables sur leur évaluation sensorielle. 
describe the same characteristic or the same term may be used to describe several characteristics. Moreover, the same term may have different meanings for different people. In order to supply the food scientists with a rational tool for a scientific description of food texture, Szczesniak (1963) proposed a classification of textural characteristics. Accordingly, astringency is a mouthfeel sensation, a textural characteristic that cannot be easily resolved on the basis of mechanical (pressure exerted on the teeth, tongue, and palate during eating) and geometrical (appearance of the food product) properties. The same descriptive terms are used to describe different flavours.

With good panel training, and by setting the descriptive terminology of the test form and the scoring scale to detect the finest possible differences, one should improve the sensitivity of the flavour test for food products and beverages (Clapperton and Harwood, 1983). However, dairy quality judging methods differ from the descriptive analysis techniques used for sensory evaluation of many other food products. In fact, descriptive terms in dairy quality judging often refer to root causes of defects rather than simple sensory experiences. Many defect oriented terms are complex concepts, since a single root cause may result in the development of multiple, distinct flavour attributes (Claassen and Lawless, 1992). For example, the general astringency term may include sensory experiences described as metallic, chalky, green flavour, rancid and oxidized (Thurston et al, 1935; St-Laurent, 1989).

Besides reporting about the term 'astringency' used to describe different defects in dairy products, this review will cover the work done in this field and also show its importance. There are at least two well documented different sources of astringency, heat treatments (Forss, 1969; Harper and Hall, 1976) and proteolytically induced peptides (Harwalkar et al, 1989). A third source, the presence of phenolic compounds, is also proposed.

\section{COMPLEXITY OF ASTRINGENCY DEFINITION}

The taste mechanism, with its three distinct parts, gustatory (tongue), tactile (touch), and olfactory (smell), depends primarily upon chemical stimulation in establishing the composite sensory response termed flavour. The tongue, with receptors located primarily on its sides and base, serves as the major organ of taste. Papillae of various types can be noted chiefly at the tip, along the sides, and at the base of the tongue. The taste buds, with which the sapid substance (in liquid form) must make contact before a taste sensation occurs, are located in many of these papillae (Bodyfelt et al, 1988; Hughes, 1992). Astringency, a sensation associated with trigeminal ganglion systems, cannot be easily defined, and is considered a tactile flavour defect described as a dry, puckery sensation in the mouth (Joslyn and Goldstein, 1964; Harwalkar, 1972a; Singleton and Noble, 1976). Astringency has been suggested by Bate-Smith (1954) to be a sensation of touch or pressure instead of taste. This sensation has also been characterized by the terms chalky, rough, dry, mouth coating or powdery because it suggests finely divided insoluble particles (Boudreau, 1980; Bassette et al, 1986). Many workers have tried to understand the mechanism by which astringent compounds impart a sensation in the oral cavity. Schiffman et al (1992b) showed that in rodents, the signals for astringent compounds are transduced by the chorda tympani nerve (a taste nerve) rather than by the trigeminal nerve. They later (Schiffman et al, 1992a) found regional differences in sensitivity to astringent compounds in the oral cavity of humans. Indeed, the glossopharyngeal nerve may be more sensitive to astringent stimuli than the nerves inner- 
vating the anterior tongue. According to Fischer et al (1992), the salivary flow rate would affect the temporal perception of astringency. Subjects having a low saliva flow-rate have thus been found to take a longer time to reach maximum intensity for astringency, and have a longer duration of this taste. These subjects are also able to rate the maximal astringency intensity of wine higher than subjects having a high saliva flow-rate.

A carry-over effect is encountered in the sensory assessment of intensely astringent samples, and it appears to increase the perceived astringency of the next sample. In order to overcome this problem, a reversedorder paired comparison tasting procedure has been devised (Arnold, 1983). The panel was divided into two groups and they tasted their pair of samples in reversed order. To compare a set of ' $m$ ' samples, it was thus necessary to have $[\mathrm{m}(\mathrm{m}-1) / 2]$ sessions to give a complete replication of all possible pairs, as within a session the same pair of samples was assessed by all testers, half in each order (Guinard et al, 1986). This procedure enabled any carry-over effect to be evaluated and eliminated, thus giving more precise estimates of parameters for comparison.

One physical effect of the presence of astringent substances is the destruction of the natural lubricant property of the saliva via precipitation of proteins and mucopolysaccharides in the mucous secretions of the salivary glands. The mucous membranes of the palate and/or tongue tend to shrink (pucker). Since its perception in the mouth is not instantaneous, astringency is thus considered as a delayed effect. Different groups of true astringents have been listed by Kudale (1970): 1) salts of multivalent metallic cations (aluminum, chromium, zinc, lead, calcium, magnesium, etc); 2) vegetable tannins (eg gallotannic acid); 3 ) dehydrating agents (eg ethyl alcohol, acetone, glycerine); and 4) mineral acids.
Thus reference solutions of aluminum potassium sulphate (alum, $1.5 \mathrm{mmol} / \mathrm{l}$ ), and $0.08 \% \mathrm{w} / \mathrm{v}$ and $0.11 \% \mathrm{w} / \mathrm{w}$ alum in water were respectively used to characterize astringency in acid or cottage cheese whey, infant formulas (Mc Gugan et al, 1979; Malcolmson and McDaniel, 1980), and plain yogurt (Harper et al, 1991). A reference standard solution of alum was also used for the detection of astringency (900 $\mathrm{ml}$ spring water $+1.2 \mathrm{~g}$ alum) in flavoured milk beverages (Lederer et al, 1991).

Since astringency is only detected when and if the sample is placed in the mouth, it is traditionally listed as a flavour defect. Flavour may be a sensory perception, a combination of taste and aroma, which are perceived respectively by the papillae on the tongue and olfactory epithelium in the nose (Schultz et al, 1967; Joglekar and Gupta, 1981). Flavour is also defined as being the net effect of several physiological reactions involving various combinations of taste, odour, mouthfeel, pain, sensibility to temperature, and kinesthetic sensations attributed to the muscular effort of chewing (Gardner, 1966). Moreover, the term 'flavour' also includes the astringent sensory property (Tobias, 1990).

More recently, Watson (1992) suggested that flavour is the additive effect of taste and smell while texture is a measurement of the physical characteristics; it usually involves the senses of sight, touch and sound. Table I shows the sense of gustation and its associated sensations (Watson, 1992).

\section{SENSORY DEFECTS INCLUDED UNDER ASTRINGENCY}

Shipe et al (1978) listed defects associated with astringency in miscellaneous along with chalkiness, while metallic off-flavour was associated with an oxidized defect although it is frequently differentiated from this defect. The metallic defect is characterized by an 
Table I. The sense of gustation and its associated sensations. Le goût et ses perceptions associées.

\begin{tabular}{lll} 
Receptor & Stimulus & \multicolumn{1}{c}{ Sensation } \\
\hline Tongue/mouth & $\begin{array}{l}\text { Water soluble } \\
\text { Chemicals }\end{array}$ & - taste (sweet, salt, acid, bitter and metallic) \\
& $-\quad$ feeling (astringency)
\end{tabular}

astringent, rough, puckery mouthfeel, and a metallic sensation similar to that observed when an iron nail or metal foil is placed in the mouth, and is due to lactates resulting from the solubilization of various metals (iron, copper and copper alloys) in lactic acid solutions. It is also generally associated with the early stages of metal-induced oxidation (Hunziker et al, 1929; Whitfield et al, 1936). Unhomogenized or cream-line milk is substantially more susceptible to the development of the metallic off-flavour than homogenized milk for reasons that are not clearly understood. However, since stainless steel has replaced monel (white metal) in milk handling and processing equipment, the metallic defect has substantially decreased as a problem. However, the presence of rust or copper in equipment or water supplies has to be avoided.

The metallic off-flavour is quite frequently encountered in dairy products such as buttermilk, sour cream, yogurt, cottage cheese and cream cheese, but may also be found in other dairy products, including butter, certain types of cheese and ice cream (Bodyfelt et al, 1988). The metallic off-flavour can be imitated by adding 1-octene-3-one to milk or cream (Shipe et al, 1978; Bassette et al, 1986).

Chalkiness is a textural (consistency) defect which is usually detected as numerous, extremely fine, undissolved particles within the masticated product. This tactile defect is described by Charalambous (1980) as being similar, if not identical, to astringency. A chalky defect is frequently encoun- tered in skim milk samples. The composition of skim milk appears to favour occurrence of this defect (off-flavour); it probably stems from the ratio of proteins to milkfat found in skim milk (Bodyfelt et al, 1988). Mechanical and thermal treatments of milk cause the formation of aggregates containing protein, fat, and lactose as well as inorganic salts of varying composition. Depending on their size, specific weight and electric charge, these aggregates either sediment or clump together on the surface of UHT or in-bottle sterilized milk, imparting chalkiness or astringency (Blanc et al, 1981; Schröder, 1983). According to Burton (1988), increasing homogenization pressure would help to reduce the occurrence or the intensity of the chalky defect in UHT milk.

Calcium fortification of cottage cheese has caused chalkiness (Puspitasari et al, 1991). However, as the report in question did not define the chalky defect or report a sandy mouthfeel, it is difficult to know if astringency was involved.

Another off-flavour, the 'green flavour', due to the formation of relatively high concentrations of acetaldehyde by the culture used in the preparation of cultured milk products (buttermilk, sour cream, kefir, Bulgarian buttermilk) may suggest a somewhat 'astringent' character. This off-flavour can be attributed to the selection of the wrong microbial strain, incubation at incorrect temperatures, and/or overincubation (Bodyfelt et al, 1988).

An 'astringent', puckery feeling perceived at the base of the tongue and upper throat 
may also describe the 'rancidity' noted in cottage cheese and other dairy products such as cream, milk and butter (Bodyfelt et al, 1988). This defect is due to the action of the enzyme lipase on milkfat and can be prevented, provided the raw milk and cream supplies were free of this defect, by proper pasteurization of all milk products used in making cottage cheese.

Various stages may be differentiated in the 'oxidized' off-flavour. A very slight intensity encountered in ice cream or ice milk makes the product flavour seem flat or missing whereas for a moderate intensity or upon a longer holding in the mouth, the sample may be described more accurately as 'astringent' metallic, or puckery. Upon incubation for 3 months at ambient room temperature, non-dairy and cow's milk powdered creamers developed an astringent off-flavour. This defect has been related to an oxidation phenomenon by Jolly and Kosikowski (1974). Heat processing of milk has an effect on its flavour; generally, the more extensive the heat treatment, the more substantial the flavour change (Joglekar and Gupta, 1981). However, the release or activation of sulphydryl groups during high heat treatment of milk $\left(>77^{\circ} \mathrm{C}\right)$ provides a protection against oxidized flavour (Tobias, 1976; Joglekar and Gupta, 1981; Bassette et al, 1986; Morr and $\mathrm{Ha}, 1991)$. Market surveys done by Jensen and Poulsen (1992) have shown that one of the flavour defects developed by retail packed cream within the stated period of shelf-life is the oxidized flavour. Resulting from oxidation of the unsaturated fatty acids in milkfat, the oxidized flavour defect may be described by the terms cardboardy and metallic. Copper-induced oxidations affect the lipid fraction of milk; in this case the phospholipids of the fat globule membrane are attacked, leading to a cardboardy flavour. As skim milk is not free from phospholipids, a copper-induced oxidized flavour development is therefore possible (Schröder, 1983). A scoring guide for astrin- gency and its flavour attributes in dairy products is suggested in table II.

\section{MECHANISM OF THE ASTRINGENT SENSATION}

More work is necessary before the mechanism of the astringent sensation can be defined and the significance of the sensation fully understood. Astringency comparison of two or more stimuli presented sequentially is difficult. Moreover, bitterness and astringency are twin sensations': oral astringency may indeed be closely linked to bitterness (Singleton and Noble, 1976; Clifford, 1986); untrained taste panellists may thus confuse astringency with bitterness (Lea and Arnold, 1978). In an attempt to determine if the tactile component (dryness) and associated taste (bitterness) component of astringency were perceptually separable, Lyman and Green (1990) found that the perception of mouth dryness increased with repeated exposure to an astringent stimulus, and that increased salivary volume reduced astringency. However, this last observation would not support the suggestion of Joslyn and Goldstein (1964), relating astringency to a reduction in, or inhibition of salivary flow. Scores for astringent and bitter off-flavour in milk are listed in table III (Shipe, 1980).

From their work on English ciders Lea and Arnold (1983) found that both bitterness and astringency were present and were due to phenolic procyanidins. While the sensation of bitterness was predominant in the oligomeric procyanidins (peaking with the tetramer), that of astringency came out top with the polymers.

\section{THEORIES ABOUT ASTRINGENCY IN MILK AND MILK PRODUCTS}

Flavour defects in milk may result from many causes. According to Shipe et al (1978), 
Table II. A suggested scoring guide for flavour of milk, cream, cultured milk products (buttermilk, sour cream, creamed cottage cheese and cultured cream butter) and dry milks.

Guide numérique proposé pour l'évaluation des différents défauts de saveur rencontrés dans le lait, la crème, les produits laitiers de culture (lait de beurre, crème sure, fromage cottage, beurre de culture) et dans les laits séchés.

\begin{tabular}{|c|c|c|c|c|c|c|c|c|c|c|c|c|}
\hline \multirow{3}{*}{$\begin{array}{l}\text { Intensity } \\
\text { of defect }\end{array}$} & \multicolumn{12}{|c|}{ Flavour defect a } \\
\hline & \multicolumn{3}{|c|}{ Milk and cream } & \multicolumn{5}{|c|}{ Cultured milk product } & \multicolumn{4}{|c|}{ Dry milks } \\
\hline & Astringent & Metallic & Rancid & Astringent & Green & Metallic & Chalky & Rancid & Astringent & Chalky & Metallic & Rancid \\
\hline Slight & 8 & 5 & 4 & 7 & 8 & 6 & 8 & 4 & 8 & 8 & 4 & 5 \\
\hline Definite & 7 & 3 & 1 & 5 & 7 & 4 & 5 & 2 & 6 & 6 & 2 & 3 \\
\hline Pronounced & 6 & 1 & 0 & 3 & 6 & 2 & 2 & 0 & $0-4$ & $0-4$ & 0 & $0-1$ \\
\hline
\end{tabular}

a A numerical score of ' 10 ' is assigned to a product free of undesirable flavours (no criticism) while an assigned score of zero (0) is indicative of an unsalable product. 
Table III. Scoring of astringent and bitter offflavour in milk.

Evaluation numérique des défauts d'astringence et d'amertume dans le lait.

Off-flavour intensity a $\frac{\text { Off-flavour }}{\text { Astringent Bitter }}$

\begin{tabular}{lll} 
Slight & 8 & 5 \\
Definite & 7 & 3 \\
Pronounced & 5 & 1 \\
\hline
\end{tabular}

a A score of 10 is given to a sample that has a typical fresh' taste and is free of undesirable flavours. Samples with off-flavours are scored lower.

seven categories of flavour defects have been defined, and are listed in table IV. Astringency is allotted to miscellaneous, a category which includes the flavour defects that either cannot be attributed to a specific cause or specifically defined in sensory terms.

During World War II, a reconstituted beverage prepared with whole milk powder was supplied to the US armed forces. However, this product was qualified as astringent and because of this defect, the reconstituted beverage was generally rejected (Patton and Josephson, 1952). This gave rise to research into the intricate chemical mechanisms involved in textural changes, particularly astringency, as this defect had been noted in raw and heated milk products (Josephson, 1954). A chalky sensation was also reported for homogenized milk shortly after its commercial introduction. However, this defect might have been caused by improper pasteurization-homogenization procedures (Shipe et al, 1978). It was thus imperative, in order to control and protect the characteristic properties of dairy foods, to know the good practices of milk transformation and maintain them in the factories.

Table IV. Categories of flavour defects in milk. Classification des défauts de flaveur du lait et identification de leur origine.

\section{Flavour alterations - descriptive or associative terms Causes}

Cooked or sulphurous, heated or rich, caramelized, scorched

Oxidized (light-induced), burnt, activated, sunlight

Rancid, goaty, soapy, butyric

Acid, malty, fruity, unclean, bitter, putrid

Oxidized, cardboard, cappy, metallic, tallowy

Feed, weed, cowy, barny

Absorbed, astringent, bitter, chalky, chemical, flat, foreign, lack freshness, salty.
Heat treatment

Exposure to various forms of radiant energy

Milk lipase catalysed hydrolysis of milk fat triglycerides

Accumulation of the products of bacterial metabolism

Reaction between molecular oxygen and lipids (oxidation)

Transmission (passage of substances from the cow's feed or surroundings to milk while it is in the udder)

Miscellaneous 


\section{Heat, astringency and heat treatments}

Milk is heat processed to eliminate pathogenic microorganisms which may be present in the raw milk and to increase the shelf-life. While heat processing can preserve the natural flavour by careful inactivation of the enzymes, treatments may also alter flavour in a more or less desirable manner during concentration and preservation stages.

Data reported by Hutton and Josephson (1951) suggested that development of astringency in heated whey was associated with heat denaturation and dehydration of the whey proteins. Milk salts were also presumed to be involved in the astringent defect. Raw skim milk and raw whey samples also developed 'roughness' when heated momentarily $\left(10 \mathrm{~min}\right.$ ) at $95^{\circ} \mathrm{C}$ (Patton and Josephson, 1952). Following ultracentrifugation in a Sharples' super-centrifuge at 35 $000 \mathrm{rpm}$, the heat coagulable substances from rennet whey were easily removed and found to be responsible for the astringency. However, as these substances were recovered with difficulty from heated skim milk, Patton and Josephson (1952) suggested that casein might exert a protective colloidal action toward the heat-coagulable whey proteins. Their observations have since been supported by Josephson et al (1967) with electron microscopy. Among the whey proteins, $\beta$-lactoglobulin was presumed to be a significant contributor to the astringent defect (Hutton and Josephson, 1951). As the astringency in dry milk was primarily attributed to the formation of insoluble calcium-protein aggregates as a result of heat treatment and drying, Josephson (1954) proposed to overcome this defect by sequestering of calcium ion activity and removal of calcium ions from the milk and/or low temperature processing of the dry milk. Tessier and Rose (1958) have also reported that heating skim milk $\left(82^{\circ} \mathrm{C}, 30 \mathrm{~min}\right)$ caused precipitation of calcium phosphate and low- ered [ $\left.\mathrm{Ca}^{2+}\right]$; skim milk was also found to contain from 2.5 to $3.4 \mathrm{mmol} \mathrm{Ca}^{2+} / /$.

Modler and Emmons (1978) have found a way to utilize acid whey obtained from cottage, bakers or cream cheese, which would otherwise be a serious disposal problem. Although neutralization of this product with an aqueous suspension of calcium oxide $(\mathrm{CaO}) 1 \mathrm{~mol} / \mathrm{l}$ has helped in reducing the sticking problem on dryer box and cyclone while spray drying, the concentrated whey was chalky and astringent (Modler and Emmons, 1977). Removal of insoluble calcium salts improved flavour and yielded a final product with characteristics close to those of sweet whey.

The increments in astringency obtained by Josephson et al (1967) on lenghtening the heat treatment of skim milk and rennet whey at $90^{\circ} \mathrm{C}$ from 10 to $30 \mathrm{~min}$ are shown in table V. Josephson et al (1967) also observed that, for a given heat treatment, a higher level of astringency was produced in rennet whey than in skim milk. Furthermore, the astringent components in whey exhibited considerably larger particle sizes, as evidenced by their sedimentation at a much lower force ( $3000 \mathrm{~g}$ for $30 \mathrm{~min}$ ) than that required for heated skim milk ( $144000 \mathrm{i}$ for $2 \mathrm{~h}$ ). In order to relate the size and struc-

Table V. Astringency intensity of heated skim milks.

Intensité de l'astringence chez des laits écrémés ayant subi différents traitements thermiques.

Sample description

Astringency intensity

1. Pasteurized skim milk

$\left(63^{\circ} \mathrm{C}-30 \mathrm{~min}\right) \quad$ No astringency

2. Heated skim milk

$\left(90^{\circ} \mathrm{C}-10 \mathrm{~min}\right) \quad$ Slight astringency

3. Heated skim milk

$\left(90^{\circ} \mathrm{C}-30 \mathrm{~min}\right) \quad$ Distinct astringency 
ture of aggregate particles to the level of astringency, Josephson et al (1967) conducted electron microscopic studies on heated whey systems: fractions free of astringency exhibited no distinct particulate components, while upon flash heating at $80^{\circ} \mathrm{C}$, spherically shaped electron-dense particles within the $30-300 \mu \mathrm{m}$ range were formed. These particles were similar in appearance to caseinate micelles in skim milk. As the degree of heat treatment was increased $\left(80^{\circ} \mathrm{C}\right.$, up to $\left.30 \mathrm{~min}\right)$, aggregates in whey systems appeared larger and more numerous, and the level of astringency was more pronounced. It appears that particle size and composition, rather than shape, accounted for astringency in heated whey systems (Bodyfelt et al, 1988).

While Josephson et al (1967) concluded that astringency in milk systems is primarily caused by heat-altered whey proteins and to some extent milk salts, both of which are associated by interaction with or adsorption on the caseinate micelles, Kratzer et al (1967) reported the presence of astringency in raw milk samples stored for $48 \mathrm{~h}$ at $4.4^{\circ} \mathrm{C}$. As a matter of fact, astringency had the second highest mean occurrence in raw milk samples (table VI).

The studies of Kratzer et al (1967) allowed the identification of many important

Table VI. Frequency of some flavour types detected in raw milk.

Fréquence de détection de quelques types de flaveur dans le lait cru.

Flavour Mean occurrence (\%) a

$\begin{array}{lr}\text { Feed } & 88.4 \\ \text { Astringent } & 12.7 \\ \text { Cowy } & 11.0 \\ \text { Oxidized } & 6.1 \\ \text { Flat } & 4.1\end{array}$

a The percentage sum is more than 100 because more than one flavour was detected in many samples. sources of variation in milk flavour (environmental factors, stage of lactation and age of the cow at calving, genetic effects and panellists for the milk evaluation). Heat alone did not account for the occurrence of astringency in raw or pasteurized milks and dry milk powders. It was therefore imperative to isolate and characterize the astringent components in raw milk and milk products to know their source.

\section{Astringency and casein breakdown products (proteolysis)}

Harwalkar (1969) was the first to report on the isolation of astringent compounds from Cheddar cheese. The isolated astringent fraction had the characteristics of a complex of associated peptides with an unusually high content of hydrophobic amino acid residues (leucine, tyrosine, valine, phenylalanine, etc) and an isoelectric point at $\mathrm{pH}$ 6.5. Some other physical and chemical properties of the astringent fraction are listed in table VII. Absorption in the 200 to $300 \mathrm{~nm}$ range had a maximum in the region of 276 $\mathrm{nm}$. The low mineral values obtained for this fraction led Harwalkar (1972a) to conclude that minerals were not involved in Cheddar cheese astringency. Strong astringency was detectable at acid or neutral $\mathrm{pH}$ but not at highly alkaline $\mathrm{pH}(>\mathrm{pH} 10)$. This loss of astringency at $\mathrm{pH} 10.5$ coincided with the ionization of the phenolic groups. The changes resulting in loss of astringency were found to be reversible, since astringency was restored by lowering the $\mathrm{pH}$. The state of ionization of phenolic groups was thus found to be important for the astringent taste (Harwalkar, 1972a).

Methods for reducing heat-induced astringency in skim milk were tested by Kudale (1970). His results showed that although treatment with ultrasonic vibrations was effective in reducing this defect, an objectionable 'burnt protein' flavour was produced. 
Table VII. Some physical and chemical properties of the astringent fraction. Quelques propriétés physiques et chimiques de la fraction astringente.

$\begin{array}{lll}\text { Property Values } & \end{array}$

Absorption spectra in the 200 to $300 \mathrm{~nm}$ range

Sedimentation velocity, $S_{20, w}$

Estimated molecular mass a

Mineral content: calcium magnesium phosphorus
$276 \mathrm{~nm}$

1.25

$9000-12000 \mathrm{Da}$

$0.04 \%$

$<0.02 \%$

$\approx 0.05 \%$

Carbohydrate

Undetectable

a Obtained by gel filtration chromatography on Sephadex (Harwalkar and Elliott, 1971; Harwalkar, 1972 a) and by size exclusion HPLC (Lemieux et al, 1989).

Proteolytic enzymes (commercial bovine pancreatic enzyme preparations, crystalline trypsin and pancreatin), when used at proper concentrations, were found to be very effective in reducing heat-induced astringency of skim milk. These findings thus supported the hypothesis that astringency in heated skim milk can be reduced by dissociation of aggregates and/or complexes of milk constituents formed as a result of heat treatment.

As reported by Demott (1971), astringency may also be produced when milk is fortified with iron salts, especially ferrous salts (ferrous sulphate, ferrous gluconate, or ferrous lactate). Shipe et al (1972) have reported that incubation of glass bead immobilized trypsin ( $2.5 \mathrm{~g}$ in each of four paddle compartments) in bulk milk samples with copper added helped to reduce the oxidized flavour. Moreover, astringency was detected if the level of immobilized trypsin exceeded $2.5 \mathrm{~g}$ per chamber. An excess of enzyme would thus increase proteolysis and cause astringency.

Later on, while investigating the influence of $\mathrm{pH}$ on astringent compounds and their extractability from cheese with a mixture of chloroform and methanol (C/M; 2/1, v/v), Harwalkar and Elliott (1971) and Harwalkar $(1972 a, b, c)$ found that only the fractions extracted from an acid Cheddar cheese or skim milk culture were astringent, while those from neutral or slightly alkaline samples were bland. The requirement for acid $\mathrm{pH}(\mathrm{pH} 4$ or 3$)$ for the extraction of astringent components would thus indicate that they are involved in a salt-type linkage. Thus at neutral or alkaline $\mathrm{pH}$, astringent components would be anionic and accordingly form salts with various cations, especially calcium, similar to the situation in milk proteins. Presumably, these salts are slightly soluble in the $\mathrm{C} / \mathrm{M}$ solvent. Solubility of astringent peptides may possibly be influenced by the ionization state; these components seemed to be less tightly bound to the curd as the ionic strength was reduced, and washing the curd with $\mathrm{pH}$-adjusted distilled water appeared to release astringent components from the curd. As the $\mathrm{pH}$ is lowered the bound calcium salt dissociates, giving rise to ionic calcium and peptides free from salt linkage. Furthermore, a low $\mathrm{pH}$ hinders ioni- 
zation of free carboxyl groups, resulting in an increase in apparent hydrophobicity, and may thereby facilitate extraction of polypeptides by moderately polar (polarity $\phi=5.0$ ) solvents such as chloroform-methanol mixtures $\left(\phi_{\mathrm{CHCl} 3}=4.3 ; \phi_{\mathrm{MeOH}}=6.6 ; \phi_{\mathrm{CHCl}}\right.$ $\mathrm{MeOH} ; 2: 1=5.0$ ).

Amino acids found in the methanolic phase (astringent fraction) of the six dried fractions (untreated original milk: whole milk or $10 \%$ non-fat dry milk; acidified milk; whey; unwashed curd; washed curd and washings) extracted with the $\mathrm{C} / \mathrm{M}$ solvent were predominantly hydrophobic residues (Harwalkar, 1972c); this is a typical characteristic of $\gamma$-casein. Moreover, polyacrylamide gel electrophoretic (PAGE) patterns for the extracts of unwashed curd, which were astringent, showed at least three faint bands in the region of whole $\gamma$-casein. It is therefore tempting to speculate that residual proteolytic activity or its reactivation is involved in the formation of astringent components in stored non-fat dry milk or pasteurized milk. This possibility seems plausible from the fact that $\beta$-caseins result from proteolytic breakdown of $\beta$-casein (Gordon et al, 1972; Gordon and Groves, 1975; Reimerdes, 1978). Since then, Harwalkar et al (1993) have confirmed this relationship between astringency in pasteurized skim milk treated with psychrotroph proteinase and plasmin and the production of breakdown products of $\beta$-casein. Indeed, they were able to show, using FPLC (fast protein liquid chromatography) and urea-PAGE (polyacrylamide gel electrophoresis) techniques, that astringent compounds from treatment of purified $\beta$-casein with plasmin were $\gamma$-casein components (fragments of $\beta$-casein consisting of residues 29-209 $\left(\gamma_{1}-\right), 106-209\left(\gamma_{2}-\right)$ and $108-209\left(\gamma_{3}-\right)$. They have thus been able to link astringency with $\gamma$-caseins. Moreover, these product levels were higher in extracts from astringent samples.

According to taste-panel results for cheese grading, aseptically manufactured
Gouda cheeses have been found by Visser $(1977 b, c)$ to contain astringent compounds. However, they were completely lacking in cheese flavour (Visser, 1977a). This may explain why Visser (1977c) was cautious about the possible contribution, as suggested by Harwalkar and Elliott (1971), of astringency to cheese flavour.

Studies on heat-treated milk samples have been done by Jaddou et al (1978). They observed that astringent off-flavour in milks heat-treated for $3 \mathrm{~s}$ (UHT) decreasing with storage time (slight astringency after $7 \mathrm{~d}$ to no astringency after $84 \mathrm{~d}$ ), while it increased linearly during storage of milks heat-treated for $90 \mathrm{~s}$ (sterilized) at $140^{\circ} \mathrm{C}$ (astringent after 1 month to very astringent after $112 \mathrm{~d}$ storage). These observations have allowed Jaddou et al (1978) to explain the latter astringency by a physical reason. Although this milk was free of astringency during the first several weeks of storage, it did show signs of gelation after 2 months, implying changes in its colloidal structure. Harwalkar (1991) has also reported about defects in UHT-sterilized milk particularly when stored at higher than ambient temperatures. From studies conducted on UHT milks (homogenized whole UHT milks $(3.5 \%$ fat)) stored in the dark for 4 months, partly at $20^{\circ} \mathrm{C}$ and partly at $1^{\circ} \mathrm{C}$, Mottar (1981) has observed, even after very intensive UHT treatments, residual proteolytic and lipolytic activities. When compared to indirectly heated UHT milk, directly heated UHT milk presented a more important loss in taste (drop in rating). Moreover, directly heated UHT milk stored at $20^{\circ} \mathrm{C}$ showed a higher degree of proteolysis and lipolysis than when stored at $1^{\circ} \mathrm{C}$. It follows that the taste pattern of UHT milk stored at $20^{\circ} \mathrm{C}$ is highly dependent on the quality of the raw milk, more particularly on the concentration of thermoresistant proteases and lipases. Proteolysis appears to affect the taste of UHT milk stored uncooled more negatively than lipolysis. Although ultra-high temperature 
treatment strongly restrains the enzymatic activities, it does not stop them completely. These observations would thus suggest a greater involvement for proteolysis than for lipolysis in astringency.

Some peptides isolated from casein treated by Pseudomonas fluorescens and Alcaligenes enzyme preparations have been found to be astringent and astringent-sour. From these findings Kostyra (1983) has suggested the following: 1 ) the sensation of astringency may depend on the hydroxyl and amide groups present in the peptides. The hydroxyl groups would be responsible for the formation of hydrogen bonds and electrostatic interactions with relevant oral cavity proteins, while the amide groups would react with nerve endings; 2 ) depending on the proportion of sour amino acids to their amides, the peptides may show predominance of sour over astringent taste or vice versa. Alcaligenes enzyme preparations also liberated bitter peptides, marked by the astringent effect of other peptides. As already mentioned, oral astringency may be closely linked to bitterness which is itself related to the average hydrophobicity of the peptides (Clifford, 1986).

As suggested by Charalambous (1980) there may be more than one combination of components that elicit an astringent response. Although, as previously mentioned, astringency has been associated with milk products that have been processed at high temperature and with proteolysis (Harwalkar et al, 1989), the presence of phenolic compounds should also be taken into consideration.

\section{Astringency and phenolic compounds}

Chemicals causing astringency are collectively known as tannins, the larger natural polyphenols (Hughes, 1992). The proanthocyanidins or condensed tannins, which characteristically bind and precipitate pro- teins, are phenolic polymers synthesized by many plants (Bate-Smith, 1954). The cow eats a lot of these plants to produce milk. Astringency results from the interaction of phenols with proteins of the mouth and saliva (Singleton and Noble, 1976). Proteins and polypeptides with a high proline content have a high affinity for tannin while glycoproteins in general seem to have low affinity for astringent phenols (Hagerman and Butler, 1981). However, casein, which is a glycoprotein found in milk, is relatively rich in proline residues when compared to the whey proteins. Thus the proline content of milk proteins varies from $\approx 1.6$ to $\approx 16.8 \%$ (caseins: $\beta$-: 35 Pro/209 residues, $16.75 \%$; $\alpha_{\text {s2 }}: 10$ Pro $/ 207$ residues, $4.83 \% ; \alpha_{s 1}: 17$ Pro/199 residues, $8.54 \%$; $\kappa-: 20$ Pro/169 residues, $11.83 \%$; whey proteins: $\beta$-lact: 8 Pro/162 residues, $4.94 \% ; \alpha$-lact: 2 Pro/ 123 residues, $1.62 \%$; BSA: 28 Pro/582 residues, $4.81 \%$ ). However, proteins are precipitated by proanthocyanidins most efficiently at $\mathrm{pH}$ values near their isoelectric points, where protein-protein electrostatic repulsion is minimized. Thus proteins with acidic isoelectric points like BSA ( $\mathrm{pl} 4.9$ ) have greater affinities for tannin at $\mathrm{pH} 4.9$ than at $\mathrm{pH} 7.8$, and basic proteins like lysozyme have higher affinities at the higher $\mathrm{pH}$ (table VIII).

Although the specificity of the interaction is a function of the size, conformation and charge of the protein molecule, $\beta$-casein should have a high affinity for the tannins at acidic $\mathrm{pH}$ due to its proline content. Harwalkar (1972a) has been able to detect astringency at acid or neutral $\mathrm{pH}$ but not at highly alkaline $\mathrm{pH}(>\mathrm{pH} 10)$. The changes in flavour at alkaline $\mathrm{pH}$ were reversible when the $\mathrm{pH}$ was lowered. Proanthocyanidin-protein interactions could thus be affected by the $\mathrm{pH}$ (Barbeau and Kinsella, 1983). Harwalkar (1972a) has observed absorption spectral changes, a shift in the maxima from 280 to $290 \mathrm{~nm}$, for the astringent fraction from acid $\mathrm{pH}$ to alkaline $\mathrm{pH}$. According to RibéreauGayon (1968), the UV absorption wave- 
Table VIII. Milk proteins, their isoelectric point and their relative affinity for tannins. Protéines du lait, leur point isoélectrique et leur affinité relative pour les tannins.

\begin{tabular}{|c|c|c|c|c|c|c|c|}
\hline & \multicolumn{3}{|c|}{ Whey proteins } & \multicolumn{4}{|c|}{ Caseins } \\
\hline & $B S A$ & $\alpha$-lact & $\beta$-lact & $\alpha_{s 1}$ & $\beta-$ & $\kappa-$ & $\alpha_{s 2^{-}}$ \\
\hline Isoelectric point a & 4.9 & 5.14 & 5.13 & $4.24-4.76$ & $4.6-5.1$ & $5.3-5.8$ & - \\
\hline Relative affinity for tannins & $B S A>$ & $\alpha$-lact $\approx$ & $\beta$-lact & $\alpha_{s 1}>$ & $\beta->$ & $\kappa-$ & - \\
\hline
\end{tabular}

a Eigel et al, 1984.

length of the simple phenols is around 270 $\mathrm{nm}$. Upon neutralization at alkaline $\mathrm{pH}$, phenolic compounds become 'phenolates' and thus have different spectral characteristics. Preliminary studies conducted by Guinard et al (1986) on acidity-astringency interactions in model solutions and wines have indicated that acidity significantly increased the astringency of the solutions tested. Moreover, since the ability of condensed tannins to precipitate proteins decreased sharply at $\mathrm{pH}$ 8.0, Guinard et al (1986) suggested that it was due to a modification of the phenol ionization of the tannins, making them therefore unavailable for hydrogen bonding. Thus an acidic $\mathrm{pH}$, by raising the percentage of tannins in the phenol form, can thereby increase the likelihood of hydrogen bonding between dihydroxyphenol groups of milk tannins and ketoimide groups of mouth proteins. Besides, Harwalkar (1972b) has concluded that astringent components should be extracted at acid $\mathrm{pH}$.
It has been observed, for English ciders, that oxidation during juice extraction was accompanied by a marked lowering in the level of the polymeric procyanidins, with consequent reduction in astringency (Lea and Timberlake, 1974). During oxidation of milk, the flavour defect changes from flat to oily (table IX).

According to Bruhn et al (1976), a good quality of green feeds is needed to reduce liability to oxidation as they have a high content of the antioxidant tocopherol. Phenolic compounds in green feeds possess many $\mathrm{OH}$ groups which, in aqueous solution, induce many hydrogen bonds to form between the tannin molecules, resulting in aggregates of various sizes.

The phenolic compounds present in milk could, upon oxidation, change the flavour of the product to an oxidized flavour and thus cause a decrease in astringency. Indeed, astringency has been shown to

Table IX. Changes in milk flavour upon oxidation

Variations dans la saveur du lait au cours de l'oxydation.

\begin{tabular}{|c|c|c|c|c|c|}
\hline Flat & $\rightarrow->$ & $\begin{array}{l}\text { Metallic } \\
\text { Astringent } \\
\text { Puckery }\end{array}$ & $\rightarrow->$ & $\begin{array}{l}\text { Oxidized } \quad . .> \\
\text { Papery } \\
\text { Cardboardy }\end{array}$ & $\begin{array}{l}\text { Oily } \\
\text { Tallowy } \\
\text { Painty }\end{array}$ \\
\hline & & & & & ishy \\
\hline
\end{tabular}


decrease with time in wine and cider (Lea and Timberlake, 1974; Charalambous, 1980). In Cheddar cheese the astringent fraction also decreased upon proteolysis during the maturation period (Lemieux et al, 1989). Gamma-caseins are proteolytic fragments of $\beta$-casein. Moreover, flavour development and stability to oxidation are influenced by proteolysis of the $\beta$-casein, which is dependent on the storage conditions (Reimerdes, 1978).

All these observations should thus suggest that phenolic compounds could also be responsible for astringency in dairy products.

\section{THE DEFECT OF ASTRINGENCY IN MILK AND MILK PRODUCTS}

Following the preceding where research has been done to try to understand and explain astringency in milk and milk products, some other works are listed in literature where the authors report about this defect. This section will be concerned about these observations and ways to reduce astringency.

\section{Fresh, concentrated, dried and UHT milks}

Identification of compounds responsible for the stale flavour defect in sterilized concentrated milk was performed by Arnold et al (1966). They found that astringency was absent from fresh whole milk, slightly present in the control sterile concentrate and more marked in stale sterile concentrate.

The flavour stability of evaporated milk produced by three different methods of processing:1) the conventional method; 2 ) the high-temperature short-time (HTST) method; and 3) the aseptic method, was determined on subsequent storage at 10 and $27^{\circ} \mathrm{C}$ (Sundararajan et al, 1966). A sig- nificant effect of processing on the initial flavour score was observed: aseptic process $>$ HTST > conventional process. However, regardless of the method of manufacture, the flavour of the products deteriorated more rapidly at 27 than at $10^{\circ} \mathrm{C}$ and showed defects such as astringency and puckery.

In a study of the effect of preheat treatment and storage of whole milk powder manufactured from New Zealand milk, astringency, which was defined as the degree to which the reconstituted milk left a drying, chalky feel in the mouth after swallowing, was evaluated. This textural characteristic (astringency) slowly increased up to 15 months, and then decreased after 18 months' storage; moreover, it was not significantly affected by the preheating conditions (Baldwin et al, 1991).

Harwalkar et al (1989) have come to the conclusion that the astringent compounds in UHT-sterilized milk, analysed by PAGE, are $\gamma$-casein-like breakdown products of casein. Although heating UHT-milk by direct-steam injection would also produce astringency, it is still not known which of the $\gamma$-caseins are astringent and if there is an optimum ratio required to elicit the astringency response (Harwalkar et al, 1993). For this purpose the amino acid composition and sequence of the astringent compounds are required.

\section{Ice cream and ice milk}

Ice cream and ice milk prepared by adding a $12 \%$ corn sweetener solution showed an astringent off-flavour. Sulphur dioxide (as bisulfite ion), 5-hydroxymethylfurfural (a sweetener impurity), ethanal (acetaldehyde), methylpropanal (isobutyraldehyde) and 3methylbutanal (isovaleraldehyde), the flavour components of the corn sweeteners, have been found responsible for this flavour defect (Olson, 1970). 


\section{Cheese}

In the early seventies cheese makers found that kasal, a blend of phosphate salts (primarily sodium aluminum phosphate, basic) could be used as an emulsifying salt up to a level of $3 \%$. Besides improving melt, appearance, texture and other characteristics of processed cheese, cheese spreads and cheese foods, kasal added no astringent off-flavours of its own (Anonymous, 1971).

In order to evaluate the role of microbially derived Strecker-type volatile compounds in commercial Cheddar cheeses, Dunn and Lindsay (1985) added phenylacetaldehyde $(500 \mathrm{ppb})$, an authentic Strecker-type volatile aldehyde, to clean-flavoured mild Cheddar cheese. They observed that phenylacetaldehyde contributed astringent and bitter sensations to the cheese flavours.

\section{Yogurt}

Out of 12 sensory descriptors used to describe plain yogurt flavour-by-mouth evaluation, astringency has been found by Harper et al (1991) to be significantly different among samples $(P \leq 0.001)$. People are more conscious nowadays about their health and want low-calorie products. Mistry and Hassan $(1990,1992)$ have developed a delactosed, high milk protein powder (HMPP) which serves as a stabilizer in nonfat yogurts to improve body and to reduce whey separation. They have thus been able to produce low-fat/non-fat yogurts from skim milk fortified with HMPP. However, when the protein content exceeds $5.6 \%$ (Hassan and Mistry, 1991) yogurts are too firm and have an astringent off-flavour.

Traditional cow milk yogurts sold in Brazil have a protein content of $3.6 \%$. However, the protein content of a yogurt analogue prepared with dry soymilk, whey solids and skim milk powder could not exceed $3.1 \%$ due to a very marked astringent off-flavour. Paolielo et al (1987) have observed that by adding calcium sulphate in small quantities $(0.104 \%$, $\mathrm{w} / \mathrm{v}$ ), they could improve overall acceptability and attain the normal protein level of $3.6 \%$ without adversely affecting consumer acceptability. Chien and Snyder (1983) have already shown that the addition (10-50\% $\mathrm{v} / \mathrm{v}$ ) of skimmed cow's milk was effective in decreasing the astringency of soymilk. The opposite has also been done. Soybean is known as an inexpensive protein and excellent energy source. For that reason soybean milk has been used to replace milk in some fermented products. Cheng et al (1990) have thus prepared sogurt, a yogurt-like soybean product. However, sogurt, a $100 \%$ soymilk product, had an astringent taste intensity higher than that of yogurt.

\section{Whey protein concentrate}

Although whey protein concentrate (WPC) is generally described as bland, flavour attributes have been associated with it. Thus, personnel tasting solutions at $5 \%$ protein of 50 WPC samples with greater than $80 \%$ protein attributed milky, sweet, soapy, bitter and astringent off-flavours to all products whereas the chalky defect was uncommon (Huffman and Marks, 1990).

Hydrolysis of raw defatted soy flour by Denapsin (an acid proteolytic enzyme) gave a product which had an excellent nutritional value without an astringent off-flavour (Moretti, 1978). Later on, this hydrolysate was used together with recovered cheese whey protein in a proportion of 3:7 (whey protein: hydrolysed soy protein) for the preparation of a soluble protein mixture neutral in flavour.

\section{Flavoured milks and formulas}

High carbonation level ( $1.42 \mathrm{CO}_{2}$ volumes) increased the sourness and astringency of 
strawberry, raspberry, peach and root beer flavoured milks (Lederer et al, 1991). Since the taste perception of sourness often stimulates the feeling of astringency (Moncrieff, 1971) and since some acids are perceived as more astringent than sour, it is suggested that the panellists could have been confused in the astringency evaluation and could have then responded to increased acidity in the flavoured milks. Thus, raising acidity has previously been suggested to increase the intensity of astringency in wine (Guinard et al, 1986). Moreover, the rate of saliva production would have thus been affected (it would have increased) by the chemical composition of the beverage, affecting the sensory magnitude of the viscosity (Szczesniak, 1979).

In a study which evaluated the sensory properties of formulas commonly replacing human milk (commercially prepared formulas based on cow's milk, home-made formulas prepared using whole and evaporated milk), Malcolmson and McDaniel (1980) found them to be all astringent, but in varying intensities. Only the whole milk formulas were found to be significantly less astringent than a reference sample made of a $0.08 \%$ alum solution and considered extremely astringent.

\section{EXTRACTION AND ISOLATION OF ASTRINGENT COMPONENTS}

This section is a summary of the different methods dealing with the extraction and isolation of astringent components from dairy products. Aqueous suspensions or solutions have been tasted for astringency by a trained panel or experienced judges. It can be observed that technologies used for the study of astringent components become more and more sophisticated with years. This way, from aggregate particles through astringent peptides, the information obtained is getting close to the identification of the astringent components.

According to Josephson et al (1967) selected milk systems, skim milk, whey and ultrafiltrate systems, have been heated at varying levels (skim milk: $82^{\circ} \mathrm{C}, 1 \mathrm{~h}$ or $80^{\circ} \mathrm{C}$, $30 \mathrm{~min}$; whey: $80^{\circ} \mathrm{C}$, flash to $30 \mathrm{~min}$; ultrafiltrate systems: boiling bath: $10-30 \mathrm{~min}$ or $80^{\circ} \mathrm{C}, 30 \mathrm{~min}$ ) to produce astringency. The astringent components were then sedimented by ultracentrifugation at different forces. Gel filtration (G-100 and G-200) on Sephadex, polyacrylamide gel electrophoresis (PAGE), electron microscopy and chemical analyses were carried out to study changes in the size, shape and composition of protein-salt aggregate particles present (Josephson et al, 1967).

The astringent components can be extracted from raw or pasteurized milk, UHT-milk and non-fat dry milk by means of the method proposed for isolating bitter and astringent compounds from Cheddar cheese (Harwalkar and Elliott, 1971). The major modification is the adjustment of the milk to $\mathrm{pH} 5.2$ and freeze-drying before extraction by C/M (Harwalkar, 1972b, c). The astringent components in these extracts have been partly purified by isoelectric precipitation at $\mathrm{pH} 7.0$ and by size-exclusion chromatography on Sephadex G-50 columns using water as a mobile phase. They have been further analysed by fast-protein liquid chromatography (FPLC) using a Mono-Q anion-exchange column and PAGE.

All the studied samples of aseptically (normal, starter-free, rennet-free and rennet-and starter-free) manufactured Gouda cheeses contained astringent compounds which have been isolated by Visser $(1977 b, c)$. The elution profile of the astringent fraction obtained, according to the method of Harwalkar and Elliott (1971), from a normal aseptic cheese after molecular sieving on Sephadex G-50 with $0.01 \mathrm{~N}$ acetic acid, showed two fractions with a molecular mass of approximately 7000 and $3000 \mathrm{Da}$, respectively. 
In order to analyse the chemical composition of Swiss cheese and to relate it to its characteristic taste, Swiss cheese samples have been fractionated into oil-soluble, water-soluble-volatile and water-solublenon-volatile components. This last fraction was found to contain astringent components which were further separated according to a modification of the procedure of Kirimura et al (1969). This process consisted of passing the water-soluble-non-volatile fraction through 5 successive Dowex 50 columns $(20 \times 200 \mathrm{~mm})$ with decreasing degree of cross-linkage ( $x 16, x 12, x 8, x 4$ and $x 2$, respectively) to allow the separation of amino acids and peptides of different sizes. The average chain length of the astringent peptides (APL) was found to increase from 1.66 to 6.06 with the reduced degree of resin cross-linkage (Biede and Hammond, 1979) and it was calculated according to the formula (Takeuchi et al, 1967): average peptide chain
length (APL) or average
number of amino acids
in the peptides

Astringent fractions have been isolated according to the method of Harwalkar and Elliott (1971) from Cheddar cheese made with added Lactobacillus strains to accelerate ripening. Size-exclusion high-performance liquid chromatography (HPSEC) on a TSK-G2000 SW column of these astringent fractions has allowed the estimation of their molecular masses at approximately 84 000-18 000 Da (Lemieux et al, 1989). Dinakar et al (1989) have also used the method of Harwalkar and Elliot (1971) to extract astringent components from Cheddar cheese prepared from cow or buffalo milk with either calf rennet or a soluble partially purified enzyme from Withania coagulans. Upon tasting, the extract from control cheese was found to be more astringent than bitter.
Knowing that the appearance of offflavours in UHT milk is partly due to the proteolysis, López-Fandiño et al (1993) have used reversed-phase HPLC (RP-HPLC) to investigate the degree of protein breakdown during storage of UHT milk. As measured by SDS-PAGE, comparison of indirectly heated UHT milk samples with directly heated UHT milk samples showed a high level of casein degradation and gave rise to peptides which eluted below or at a concentration of $35 \%$ solvent B $(0.1 \%$ trifluoroacetic acid in acetronitrile). The peptides so obtained were derived from the action of Pseudomonas fluorescens strain B52 proteinase on casein and eluted before the proteose-peptone, $\alpha$-lactalbumin and $\beta$-lactoglobulin. According to López-Fandiño et al (1993), this RP-HPLC method could help to predict the risk of deterioration on storage of freshly prepared milks and would throw out a hint that the origin of astringency in UHT milk might not be due to whey proteins.

\section{ASTRINGENT PEPTIDES}

Kirimura et al (1969), in their study on the contribution of peptides and amino acids to the taste of foodstuffs, found that dipeptides involving the $\gamma-\mathrm{COOH}$ group of glutamic acid (Glu) in the peptide linkage are astringent. The assumption is supported by Nishimura and Kato (1988) who established that the peptides listed in table $\mathrm{X}$ are astringent.

Astringency has been found to be one of the eight flavour characteristics of acid or cottage cheese whey. In order to increase the utilization of whey in foods, McGugan et al (1979) have mixed it with skim milk in various proportions. Since astringency was found to be present at different levels, they have thus reported that change in astringency could result from changes in the ionized forms of astringent peptides. 
Table X. Dipeptides tasted in $0.2 \%$ aqueous solution and evaluated by a trained panel as being astringent

Dipeptides ayant été évalués à une concentration de $0,2 \%$ en solution aqueuse et identifiés comme étant astringents par des panellistes entraînés.

\section{$\gamma$-L-Glu-Glya $\gamma$-L-Glu-L-Val $\gamma$-L-Glu-L-Tyr ${ }^{b}$ $\gamma$-L-Glu-L-Alaa $\gamma$-L-Glu-L-Leu $\gamma-$-L-Glu-L-Pheb $\gamma$-L-Glu-L-Ser $\gamma$-L-Glu-L-lle $\gamma$-L-Glu-L-Aspa $\gamma$-L-Glu-L-Thr $\gamma$-L-Glu-L-Trp $\gamma$-L-Glu-L-Glua $\gamma$-L-Glu-L-Pro}

- Accompanied by sourness

b Accompanied by sourness and bitterness.

\section{CONCLUSION}

Being handled extensively between production and consumption, milk comes into contact with many plant surface equipments and it is thus prone to many potential sensory changes. These are the main causes of potential sensory changes in milk: i) accidental contamination with chemicals; ii) milk treatments, in particular thermal processing; iii) and reactions during storage due to: a) microbial growth; b) enzymatic or oxidative activity.

Knowing that a successful sensory analysis depends more on people than on methods, experimental designs and computers, a good panel training and a well defined descriptive terminology of the test form and of the scoring scale are thus necessary.

To describe some associated textural defects of dairy products, there is no stated consensus among the sensory evaluators of dairy products in their understanding and use of the attributes or terms for ratings. Thus regarding the confusion around the use of the term 'astringent' a consensus in dairy judging becomes imperative.

From the results mentioned above it appears that astringency arises in treated milk from at least three different sources: 1) from heat-induced association of whey proteins and calcium phosphate with the caseinate system (Josephson et al, 1967); 2) they may be proteolytically induced peptides. In non-fat dry milk samples the astringent components have been shown to be polypeptides associated with the casein fraction, particularly $\gamma$-casein (Harwalkar, 1972c). Moreover, mineral content (calcium, magnesium and phosphorus) has not been shown to be involved, and heat alone cannot account for this defect. Astringent components can be extracted only from acidified milk; and 3) they may involve phenolic compounds which are always present in the feeds given to cows.

Ultrasonic vibrations and treatment with proteolytic enzymes (trypsin and pancreatin) have been found to reduce astringency in heated skim milk by the dissociation of aggregates and /or complexes of milk constituents formed as a result of heat treatment (Kudale, 1970). One could establish points of similarity between Kudale's observations and cheese proteolysis, where the astringency is reduced through the degradation of proteins (caseins) to free amino acids. Indeed, proteolytic breakdown during the cheese ripening process (rennet, starter strain, bacteria, etc) implies the degradation of high molecular mass polypeptides (astringent fraction, with $M_{\mathrm{r}}$ of $\approx 84000$ to $18000 \mathrm{Da}$ ) to peptides and free amino acids (Lemieux et al, 1989) with a loss of astringency.

Although the role of peptides contributing to the bitter taste in cheese has been studied in detail, further research is necessary to explain the contribution of peptides to food taste. The consumer is the final and decisive judge of eating quality. Acceptance of a food is influenced to a great extent by the tactile properties exhibited by it. Producers should thus supply food products with no assigned defect. They thus should try to minimize the effects of processing. More 
interest should also be directed towards the equilibrated sensation to make a dairy product appetizing and satisfying so that the consumer will appreciate and become fond of it. For example, for a frozen dairy dessert to retain its refreshing and pleasing characteristics, the mouthfeel should not be excessively cold, dry or astringent (Bodyfelt et al, 1988).

Astringency should stimulate more interest among workers involved in the field of dairy products. More effort should thus be involved in the astringent defect in dairy products to try to understand it and find the exact causes.

\section{ACKNOWLEDGMENT}

We would like to thank Dr VR Harwalkar for his helpful suggestions during the preparation of this manuscript.

\section{REFERENCES}

Anonymous (1971) Phosphate blend saves up to $\$ 6000$ per million lb processed cheese. Food Process, 32, 20-21

Amold GM (1983) A tasting procedure for assessing bitterness and astringency. In: Sensory quality in foods and beverages: definition, measurement and control (Williams AA, Atkin RK, eds) Ellis Horwood Limited, Chichester, England, 109-114

Arnold RE, Libbey LM, Day EA (1966) Identification of components in the stale flavor fraction of sterilized concentrated milk. J Food Sci 31, 566-573

Baldwin AJ, Coope HR, Palmer KC (1991) Effect of preheat treatment and storage on the properties of whole milk powder. Changes in sensory properties. Neth Milk Dairy J 45, 97-116

Barbeau WE, Kinsella JE (1983) Factors affecting the binding of chlorogenic acid to fraction 1 leaf protein. J Agric Food Chem 31, 993-998

Bassette R, Fung DYC, Mantha VR (1986) Off-flavors in milk. CRC Crit Rev Food Sci Nutr 24, $1-52$
Bate-Smith EC (1954) Astringency in foods. Food Process Packag 23, 124-127, 135

Biede SL, Hammond EG (1979) Swiss cheese flavor. I. Chemical analysis. J Dairy Sci 62, 227-237

Blanc B, Odet G, Adda J, Bosset JO, Rüegg M (1981) New monograph on UHT milk. Appearance, flavor and texture aspects: recent developments. Int Dairy Fed Bull 133, 25-48

Bodyfelt FW, Tobias J, Trout GM (1988) The sensory evaluation of dairy products. Reinhold, Van Nostrandreinhold, New York, 598 p

Boudreau JC (1980) Taste and the taste of foods. A review and a report on a Symposium. Naturwissenschaften $67,14-20$

Bruhn JC, Franke AA, Goble GS (1976) Factors relating to development of spontaneous oxidized flavor in raw milk. J Dairy Sci 59, 828-833

Burton $\mathrm{H}$ (1988) Ultra-high-temperature processing of milk and milk products. Elsevier, Barking, $354 p$

Charalambous G (1980) The analysis and control of less desirable flavors in foods and beverages. Academic Press, New York, 358 p

Cheng YJ, Thompson LD, Brittin HC (1990) Sogurt, a yogurt-like soybean product: development and properties. J Food Sci 55, 11781179

Chien JT, Snyder HE (1983) Detection and control of soymilk astringency. J Food Sci 48 , 438-440

Claassen M, Lawless HT (1992) Comparison of descriptive terminology systems for sensory evaluation of fluid milk. J Food Sci 57,596 600,621

Clapperton JF, Harwood JB (1983) Flavour description and flavour classification. In: Sensory quality in foods and beverages: definition, measurement and control (Williams AA, Atkin RK, eds) Ellis Horwood Limited, Chichester, England, 82-88

Clifford MN (1986) Phenol-protein interactions and their possible significance for astringency. In: Interactions of food components (Birch GG, Lindley MG, eds) Elsevier, London, 143163

Demott BJ (1971) Effects on flavor of fortifying milk with iron and absorption of the iron from intestinal tract of rats. J Dairy Sci 54, 16091614 
Dinakar P, Mathur MP, Datta Roy D (1989) Differences in proteolytic behaviour in Cheddar cheese prepared with calf and vegetable rennet. Indian J Dairy Sci 42, 792-796

Dunn HC, Lindsay RC (1985) Evaluation of the role of microbial Strecker-derived aroma compounds in unclean-type flavors of Cheddar cheese. J Dairy Sci 68, 2859-2874

Eigel WN, Butler JE, Ernstrom CA, Farrell HM, Harwalkar VR, Jenness R, Whitney R McL R (1984) Nomenclature of proteins of cow's milk: fifth revision. J Dairy Sci 67, 1599-1631

Fischer U, Boulton R.B, Noble AC (1992) Eftect of salivary flow rate on temporal perception of bitterness and astringency. Chem Senses 16 , 521-522

Forss DA (1969) Flavors of dairy products: a review of recent advances. J Dairy Sci 52 , 832-840

Gardner WH (1966) Food acidulants. Allied Chemical Corp, New York, $185 \mathrm{p}$

Gordon WG, Groves ML (1975) Primary sequence of beta, gamma, and minor caseins. J Dairy Sci 58, 574-582

Gordon WG, Groves ML, Greenberg R, Jones $\mathrm{SB}$, Kalan EG, Peterson RF, Townend RE (1972) Probable identification of $\gamma$-, TS-, Rand $S$ - caseins as fragments of $\beta$-casein. J Dairy Sci 55, 261-264

Guinard JX, Pangborn RM, Lewis MJ (1986) Preliminary studies on acidity-astringency. Interactions in model solutions and wines. J Sci Food Agric 37, 811-817

Hagerman AE, Butler LG (1981) The specificity of proanthocyanidin-protein interactions. $J$ Biol Chem 256, 4494-4497

Harper WJ, Hall CW (1976) Dairy technology and engineering. The AVI Publishing Co Inc, Westport, Connecticut, $631 \mathrm{p}$

Harper SJ, Barnes DL, Bodyfelt FW, Mc Daniel MR (1991) Sensory ratings of commercial plain yogurts by consumer and descriptive panels. J Dairy Sci 74, 2927-2935

Harwalkar VR (1969) Isolation and partial characterization of an astringent tasting component from Cheddar cheese. J Dairy Sci 52 , 885

Harwalkar VR (1972a) Characterization of an astringent flavor fraction from Cheddar cheese. J Dairy Sci 55, 735-741
Harwalkar VR (1972b) Influence of hydrogen ion concentration on extractability and flavor of bitter and astringent flavor components from Cheddar cheese and cultured milk. J Dairy Sci $55,742-743$

Harwalkar VR (1972c) Isolation and partial characterization of an astringent fraction from milk and nonfat dry milk. J Dairy Sci 55, 1400-1404

Harwalkar VR (1991) Storage defects in UHTsterilized milk. J Dairy Sci 74 (suppl 1), 81

Harwalkar VR, Elliott JA (1971) Isolation of bitter and astringent fractions from Cheddar cheese. J Dairy Sci 54, 8-11

Harwalkar VR, Boutin-Muma B, Cholette $H$, McKellar RC, Emmons DB, Klassen G (1989) Isolation and partial purification of astringent compounds from ultra-high temperature sterilized milk. J Dairy Res 56, 367-373

Harwalkar VR, Cholette H, McKellar RC, Emmons DB (1993) Relation between proteolysis and astringent off-flavor in milk. J Dairy Sci 76 , 2521-2527

Hassan HN, Mistry VV (1991) Production of low fat yogurt from a high milk protein powder. J Dairy Sci 74 (suppl 1), 96

Huffman LM, Marks PK (1990) Characteristic flavours of whey protein concentrates. In: Brief Communications and Abstracts of Posters of the 23rd Int Dairy Congr (FIL). Montreal, Canada, $511 \mathrm{p}$

Hughes N (1992) The tasting phenomenon. Nutr Food Sci 23, 4-6

Hunziker OF, Cordes WA, Nissen BH (1929) Metals in dairy equipment. Metallic corrosion in milk products and its effect on flavor. $J$ Dairy Sci 12, 140-181

Hutton JT, Josephson DV (1951) A tactual flavor defect of dried milk. J Dairy Sci 34, 488

Jaddou HA, Pavey JA, Manning DJ (1978) Chemical analysis of flavour volatiles in heat-treated milks. J Dairy Res 45, 391-403

Jensen GK, Poulsen HH (1992) Sensory aspects. Bull Int Dairy Fed 271, 26-31

Joglekar S, Gupta SK (1981) Effect of heat processing on the flavour of milk and milk products. Indian Dairyman, 33, 143-147

Jolly RC, Kosikowski FV (1974) Fat characteristics and stability of nondairy and dairy powdered creamers. J Agric Food Chem 22, 295298 
Josephson DV (1954) Flavor origins - Review of chemical mechanisms affecting flavor acceptability of dairy products. J Agric Food Chem 2, 1182-1185

Josephson RV, Thomas EL, Morr CV, Coulter ST (1967) Relation of heat-induced changes in protein-salt constituents to astringency in milk systems. J Dairy Sci 50, 1376-1383

Joslyn MA, Goldstein JL (1964) Astringency of fruits and fruit products in relation to phenolic content. Adv Food Res 13, 179-217

Kirimura J, Shimizu A, Kimizuka A, Ninomiya T, Katsuya N (1969) The contribution of peptides and amino acids to the taste of foodstuffs. J Agric Food Chem 17, 689-695

Kostyra $H$ (1983) Characteristics of astringent, astringent-sour, and bitter peptides liberated from casein by Pseudomonas and Alcaligenes enzyme preparation. Zesz Nauk Akad Roln Tech Olszt, Technol Zywn 18, 5-32

Kratzer DD, Foreman CF, Freeman AE, Bird EW, Rosenberger WS, Nelson FE (1967) Important sources of variation in milk flavor. J Dairy Sci 50, 1384-1389

Kudale JM (1970) An investigation of methods for reducing astringency in heated skimmilk. $\mathrm{Ph} \mathrm{D}$ thesis, University of Minnesota, U-M-I Dissertation Services, 70-20209

Land DG (1983) What is sensory quality. In: Sensory quality in foods and beverages: definition, measurement and control (Williams AA, Atkin RK, eds) Ellis Horwood Limited, Chichester, England, 15-29.

Lea AGH, Timberlake CF (1974) The phenolics of ciders. 1. Procyanidins. J Sci Food Agric 25, 1537-1545

Lea AGH, Arnold GM (1978) The phenolics of ciders: Bittemess and astringency. J Sci Food Agric 29, 478-483

Lea AGH, Arnold GM (1983) Bitterness, astringency and the chemical composition of ciders. In: Sensory quality in foods and beverages: definition, measurement and control (Williams AA, Atkin RK, eds) Ellis Horwood Limited, Chichester, England, 203-211

Lederer CL, Bodyfelt FW, McDaniel MR (1991) The effect of carbonation level on the sensory properties of flavored milk beverages. J Dairy Sci 74, 2100-2108

Lemieux L, Simard RE (1991) Bitter flavour in dairy products. I. A review of the factors likely to influence its development mainly in cheese manufacture. Lait 71, 599-636

Lemieux L, Simard RE (1992) Bitter flavour in dairy products. II. A review of bitter peptides from caseins: their formation, isolation and identification, structure, masking and inhibition. Lait 72, 335-382

Lemieux L, Puchades R, Simard RE (1989) Sizeexclusion HPLC separation of bitter and astringent fractions from Cheddar cheese made with added Lactobacillus strains to accelerate ripening. J Food Sci 54, 1234-1237

López-Fandiño R, Olano A, San José C, Ramos M (1993) Application of reversed-phase HPLC to the study of proteolysis in UHT milk. J Dairy Res 60, 111-116

Lyman BJ, Green BG (1990) Oral astringency: Effects of repeated exposure and interactions with sweeteners. Chem Senses 15, 151-164

Malcolmson LJ, McDaniel MR (1980) Magnitude estimation of infant foods. II. Taste, texture and odor of infant formulas. Can Inst Food Sci Technol J 13, 56-63

Mc Gugan WA, Larmond E, Emmons DB (1979) Some observations on the flavor of acid whey. Can Inst Food Sci Technol J 12, 32-35

Mistry VV, Hassan HN (1990) Manufacture of low fat yogurt using a high protein powder. In: Brief Communications and Abstracts of Posters of the 23rd Int Dairy Congr (FIL). Montreal, Canada. 518

Mistry VV, Hassan HN (1992) Manufacture of nonfat yogurt from a high milk protein powder. J Dairy Sci 75, 947-957

Modler HW, Emmons DB (1977) Spray drying acid whey treated with calcium. J Dairy Sci 60 (suppl 1), 38-39

Modler HW, Emmons DB (1978) Calcium as an adjuvant for spray-drying acid whey. J Dairy Sci 61, 294-299.

Moncrieff RW (1971) The sour taste. Flavour Ind 2, 84-86

Moretti RH (1978) Production of acid soluble soy protein by enzymatic hydrolysis. In: Abstracts 5 th Congress - Intemational Congress of Food Science and Technology. Kyoto, Japan, 233

Morr CV, Ha EYW (1991) Off-flavors of whey protein concentrates: a literature review. Int Dairy $J 1,1-11$

Mottar J (1981) Heat resistant enzymes in UHT milk and their influence on sensoric changes 
during uncooled storage. Milchwissenschaft $36,87-91$

Nishimura T, Kato $\mathrm{H}(1988)$ Taste of free amino acids and peptides. Food Rev Int 4, 175-194

Olson RL (1970) Removal and identification of some flavor constituents from corn sweeteners. Diss Abstr Int - B - Sci Eng 31, 2045

Paolielo MMB, Reddy KV, Da Silva RSF (1987) Calcium sulphate as organoleptic coadjuvant in the formulation of soy-whey yoghurt. Lebensm Wiss Technol 20, 155-157

Patton S, Josephson DV (1952) Observations on the tactual flavor qualities of heated milk. J Dairy Sci 35, 161-165

Puspitasari NL, Lee K, Greber JL (1991) Calcium fortification of Cottage cheese with hydrocolloid control of bitter flavor defects. J Dairy Sci $74,1-7$

Reimerdes EH (1978) The enzymatic degradation of $\beta$-casein and its technological significance. In: Abstracts 5th Congress - International Congress of Food Science and Technology. Kyoto, Japan. 232

Ribéreau-Gayon $\mathrm{P}$ (1968) Les composés phénoliques des végétaux. Dunod, Paris. $254 \mathrm{p}$

Rouseff RL (1990) Bitterness in Foods and Beverages-Developments in Food Science 25. Elsevier, New York, $356 \mathrm{p}$

Schiffman SS, Simon SA, Graham BG (1992a) Regional differences in sensitivity to astringent compounds in the oral cavity of humans. Chem Senses 16, 575

Schiffman SS, Simon SA, Suggs MS, Sostman AL (1992b) Comparison of chorda tympani and trigeminal nerve responses to astringent compounds in rodents. Chem Senses 16, 576

Schröder MJA (1983) Aspects of sensory quality in milk and unfermented milk products. In: Sensory quality in foods and beverages: definition, measurement and control (Williams AA, Atkin RK, eds) Ellis Horwood Limited, Chichester, England, 401-411

Schultz HW, Day EA, Libbey LM (1967) Symposium on Foods: The chemistry and physiology of flavours. AVI Publishing Co Inc, Westport, Connecticut. $535 \mathrm{p}$

Shipe WF (1980) Analysis and control of milk flavor. In: The analysis and control of less desirable flavors in foods and beverages (Charalambous G, ed) Academic Press, New York. 201-239
Shipe WF, Senyk G, Weetall HH (1972) Inhibition of oxidized flavor development in milk by immobilized trypsin. J Dairy Sci 55,647 648

Shipe WF, Bassette R, Deane DD, Dunkley WL, Hammond EG, Harper WJ, Kleyn DH, Morgan ME, Nelson JH, Scanlan RA (1978) Offflavors of milk: nomenclature, standards and bibliography. J Dairy Sci 61, 855-869

Singleton VL, Noble AC (1976) Wine Flavor and Phenolic Substances. In: phenolic, sulfur, and nitrogen compounds in food flavors. Am Chem Soc (ACS) Symp Ser 26 (Charalambous G, Katz I, eds) Washington, USA. 47-70

St-Laurent AM (1989) Le goût de craie du lait: un lien avec l'alimentation hivernale. Prod Lait Mars, 13

Sundararajan NR, Muck GA, Whitney R McL, Tobias J (1966) Flavor of evaporated milk. II.Changes in flavor on storage of evaporated milk made by three processes. J Dairy Sci 49 , 166-172

Szczesniak AS (1963) Classification of textural characteristics. J Food Sci 28, 385-389

Szczesniak AS (1979) Classification of mouthfeel characteristics of beverages. In: Food texture and theology (Sherman P, ed) Academic Press, London, 1-20

Takeuchi T, Yoshii T, Yoshii H (1967) Peptides in miso and soy sauce. IV. Relation between the $\mathrm{C} / \mathrm{N}$ ratio of the raw materials and the distribution patterns of peptides in miso. Hakko Kogaku Zasshi (J Ferment Technol) 45, 29-33

Tessier H, Rose D (1958) Calcium ion concentration in milk. J Dairy Sci 41, 351-359

Thurston LM, Carson Brown W, Dustman RB (1935) Oxidized flavor in milk. I. The probable relation of lecithin to oxidized flavor. J Dairy Sci $18,301-306$

Tobias J (1976) Organoleptic properties of dairy products. In: Dairy technology and engineering (Harper WJ, Hall CW, eds) The AVI Publishing Co Inc, Westport, Connecticut. 75-140

Tobias J (1990) Compositional elements affecting flavor of dairy foods: Formulated foods. J Dairy Sci 73, 3657-3663

Visser FMW (1977a) Contribution of enzymes from rennet, starter bacteria and milk to proteolysis and flavour development in Gouda cheese. 2. Development of bitterness and cheese flavour. Neth Milk Dairy J 31, 188209 
Visser FMW (1977b) Contribution of enzymes from rennet, starter bacteria and milk to proteolysis and flavour development in Gouda cheese. 3. Protein breakdown: analysis of the soluble nitrogen and amino acid nitrogen fractions. Neth Milk Dairy J 31, 210-239

Visser FMW (1977c) Contribution of enzymes from rennet, starter bacteria and milk to proteolysis and flavour development in Gouda cheese. 5. Some observations on bitter extracts from aseptically made cheeses. Neth Milk Dairy J 31, 265-276

Watson M (1992) Sensory characteristics of food. Nutr Food Sci 23, 4-6

Whitfield BH, Davis HP, Downs PA (1936) The effect of milk upon metals and metals upon milk. J Dairy Sci 19, 27-28 